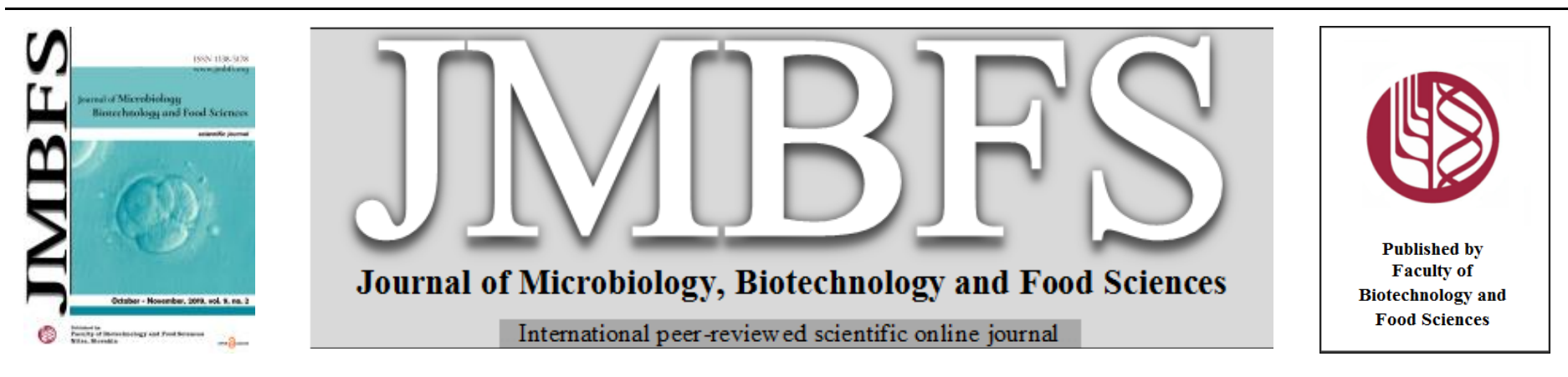

\title{
ACTINOMYCETES ISOLATED FROM WETLAND AND HILL PADDY DURING THE WARM AND COOL SEASONS IN SARAWAK, EAST MALAYSIA
}

\author{
Ann Anni Basik*, Holed Juboi, Sunita Sara Gill Shamsul, Jean-Jacques Sanglier and Tiong Chia Yeo
}

Address(es): Ann Anni Basik

${ }^{1}$ Sarawak Biodiversity Centre, Km. 20 Jalan Borneo Heights, Semengoh, 93250 Kuching, Sarawak, Malaysia.

*Corresponding author: annbasik@sbc.org.my

doi: 10.15414/jmbfs.2020.9.4.774-780

\section{ARTICLE INFO}

Received 12.3. 2018

Revised 4. 9. 2019

Accepted 11.9. 2019

Published 3. 2. 2020

\section{Regular article}

open $\mathcal{O}$ access

\begin{abstract}
As part of the Natural Product Discovery programme at Sarawak Biodiversity Centre (SBC), our study targeted isolation and evaluation of actinomycetes diversity from paddy rice fields. Samples from two types of paddy farming system practiced in Sarawak, wet land and hill paddy, were collected and processed leading to the selection of 578 strains distributed among 24 genera and 10 families. Analysis using phylogenetic clustering indicated a total of 159 taxonomic units (TU). The taxonomic position and the ranking of the TU allowed their classification in 4 novel species, 61 putative novel species and 94 known species or species of uncertain position. The high genus diversity and percentage of novel or putative novel species demonstrate the biodiversity potential of Sarawak ecosystems, even in manmanaged ecosystems.
\end{abstract}

Keywords: paddy field, actinomycetes, ranking, taxonomic unit

\section{INTRODUCTION}

Isolation of rare actinomycetes from paddy rice (Oryza sativa L.) field in the Kuching Division, Sarawak were made to evaluate their diversity and distribution. Paddy is the third most widely planted crop in Malaysia $\left(6880 \mathrm{~km}^{2}\right)$ after oil palm and rubber (DOA, 2011), with Sarawak being the nation's fourth largest rice producer, after Kedah, Perak and Kelantan (Sarawak Energy, 2013). Rice is cultivated either in marshy, lowland areas, periodically flooded or hilly regions where natural rainfall provides adequate amount of water (Joshi, 2002) Wetland paddy represents an intermediate system between terrestrial ecosystems and aquatic ecosystems (Liesack et al., 2000; Kazutake, 2007; Ding et al., 2014). In hill paddy, slash-and-burn crop cycle is practiced with 3-30 years long fallow period which allows reconstitution of dense secondary formations, a biomass source of fertility for the next planting cycle (MARDI, 2011). The uniqueness of paddy environment have led to the isolation of novel genera such as Oryzihumus (Kageyama et al., 2005), Humihabitans (Kageyama et al., 2007) Humibacillus (Kageyama et al., 2008) and Actinophytocola (Indananda et al. 2010).

In response to the ecological stress and survival mechanisms, soil microorganisms are induced to release bioactive compounds. Secondary metabolites obtained from Actinomycetes provide a potential source of many novel compounds with antibacterial, antitumour, antifungal, antiviral, antiparasitic and other properties (Genilloud et al., 2011; Omura, 2011; Solecka et al., 2012). For instance, a novel antibacterial compound Clostomicin was isolated from Micromonospora echinospora subsp. Arminiaca KMR593 isolated from paddy soil (Takahashi et al., 1986). Since then, the biotechnological potential of actinomycetes from paddies have not been efficiently exploited.

Soils in managed agricultural systems often differ from the unmanaged systems (Jangid et al., 2008; Wu et al., 2008; Lauber et al., 2013). Actinomycetes have beneficial roles in soil nutrients cycling and agricultural productivity which have led to reports on higher population of actinomycetes in agricultural land compared to forest soils (Burck et al., 1989; Elliot and Lynch, 1995; Lopes $\boldsymbol{e}$ al., 2011). Soil microbial ecosystem also function as a sensitive biological marker, useful to identify ecosystem condition, disturbance and damage (Roper and Ophel-Keller, 1997).

In this paper we propose an approach allowing better evaluation of the isolated strains diversity and distribution through ranking and clustering analysis. A prokaryotic species is considered to be a group of strains that are characterized by a certain degree of phenotypic consistency, showing over $70 \%$ of DNA-DNA binding and traditionally over $97 \%$ of $16 \mathrm{~S}$ ribosomal RNA (rRNA) gene- sequence identity (Gevers et al., 2005). However, species can be differentiated at a level of 98.2 - $99 \%$ 16S rRNA similarity (Kim et al., 2014).

Apart from the commonly collected soil samples, rhizospheric soil and roots were also included for the isolation of actinomycetes in this project. Rhizospheric soil is the ecological zone surrounding the roots of growing plants and are affected by the plant root activities (Plaster, 2002; Doi et al., 2010). Rhizospheric soils also have high nutrient content leading to higher microbial load (Adegboye and Babalola, 2012). Rice roots provide polysaccharides, amino acids and organic acids (Rovira, 1969; Kimura, 1977; 1983). Actinomycetes in the rhizophere produce antibiotics in the vast majority of cases protecting the plants (Compant et al., 2010). As a result, the community structures of soil microorganisms in the rice rhizosphere are expected to differ significantly from the same paddy field bulk soil (Doi et al., 2010).

Endophytes are common in plants, with an estimated of 1 million species yet to be discovered (Joseph and Priya, 2011). Interest in investigating endophytic actinomycetes are due to the microbes' ability to produce anti-microbials, extracellular enzymes and their involvement with bioremediation and biocontrol (Inderiati and Franco, 2008; Gangwar et al., 2012; Chankhamhaengdecha et al., 2013). Therefore, such samples were also taken into consideration.

\section{MATERIALS AND METHODS}

\section{Site Description}

Both study sites are located in the Kuching Division, Sarawak, East Malaysia The study area has a tropical climate with uniform temperatures through the year, ranging from $32{ }^{\circ} \mathrm{C}$ during the day to $28{ }^{\circ} \mathrm{C}$ at night (Dominick et al., 2012). Rainfall is common throughout the year averaging $4000 \mathrm{~mm}$ per annum (Gandaseca, 2014). Conditions are drier between April and June, while the wettest months are between December to February. Relative humidity ranges from $57 \%$ to $100 \%$ over the course of the year, rarely dropping below $47 \%$ (WeatherSpark 2013).

\section{Hill Paddy}

Hill paddy field in this study is located at Padawan (N01 ${ }^{\circ} 13.248^{\prime}$ E $110^{\circ}$ $\left.18.680^{\prime}\right)$. The half hectare paddy field was planted along a hill slope. The site was a secondary forest before it was cut and burn for paddy planting. Paddy were planted using seeds, once or twice in a year with a growth period of five months before they can be harvested. Other food crops were planted at areas having high ash content among the paddy plants like maize, vegetables, and short-life fruit 
trees such as bananas and papayas. A total of $500 \mathrm{~kg} \mathrm{hectare}^{-1}$ fertiliser (NPK 12:12:17) is applied twice, one month after planting and two to three month before harvesting. The area will then be left to recover for at least a year for the next cut and burn cycle.

\section{Wetland Paddy}

The one-hectare wetland paddy field located in Serian (N01 $08.880^{\prime} \mathrm{E} 110^{\circ}$ $29.053^{\prime}$ ') is part of the 10 hectares paddy plots that are farmed for generations This field plot is irrigated by canals from a nearby river. A total of $500 \mathrm{~kg}$ hectare $^{-1}$ fertiliser (NPK 12:12:17) are applied evenly throughout the field twice (one week after planting the seedlings and two months before harvesting).

\section{Sample Collection}

The samples (soil, rhizospheric soil and rice roots) were collected in December (high rainfall, 500-700 mm) and February/March (low rainfall, 200-300 mm) 2011 and 2012 from wetland and hill paddy field plots. Second sample collection was conducted prior to the harvest.

Uneven distribution of microorganisms is often a limiting factor during ecological studies (Girvan et al., 2004; Schwarzenbach et al., 2007; Wolfe et al., 2007). Potential bias is minimised by collecting samples at different spots in each study area and mixing them into a composite sample (Silva et al., 2013). For this study, four composite samples from each paddy field environment were collected. Composite soil samples from each plot were mixtures of three sub samples. Soil samples were collected at regular grid spacing from the upper $(0-$ $10 \mathrm{~cm}$ ) soil layers. For wetland paddy, subsamples were taken at $2 \mathrm{~m}$ apart. As for hill paddy, subsamples were taken from two different sites based on elevation. Sampling apparatus were cleaned with $70 \%$ ethanol for each collection. Rhizospheric soil were taken from soil attached to the rice plant roots

Inappropriate storage conditions of the soil samples can adversely affect microbial communities (Trabue et al., 2006; Zornoza et al., 2006). To avoid overgrowth of fast-growing microorganisms and maintaining the microbia composition, soil samples were kept in zip lock bags/ bottles. Root samples were kept in tubes with $40 \%$ glycerol. Collected samples were then placed in cool box during the expedition.

\section{Soil Sample Analysis}

The subsamples for each paddy site were thoroughly mixed, air-dried for 2 weeks at room temperature and then stored in plastic containers prior to the analysis. Air dried soil sample analysis, excluding $\mathrm{pH}$, were conducted by the Department of Agriculture, Kuching, Sarawak. Soil pH was measured using a 1:5 (w/v) ratio of freshly collected soil to water (Ellis and Foth, 1996). CEC was measured using distillation method (Malaysia Standard, 1980). Total organic carbon (TOC) was determined using instrumental dry combustion method using Multiphase Organic Carbon Analyzer. Available phosphorus (P) by method based on Bray and Kurtz (1945). Exchangeable cations analysis was carried out by leaching the soil with neutral ammonium acetate (Malaysia Standard, 1980). The concentrations of the base cations in the leachate are determined by Inductively Coupled Plasma-Optical Emission Spectroscopy (ICP-OES) 7300 DV.

\section{Actinomycetes Isolation}

\section{Pre-treatment of Samples}

Rhizospheric soil was taken from soil still attached to the paddy plant roots. Rhizospheric soil and soil samples collected were air-dried at room temperature for 7 days, ground and sieved. With exception of roots, the samples were then processed with various pre-treatments and enrichment techniques namely:

- AD, Air Drying: $1 \mathrm{~g}$ of soil, air dried for 7 days (Labeda, 1990)

- HT, Heat Treatment: $1 \mathrm{~g}$ of air-dried soil were heated at $120^{\circ} \mathrm{C}$ for 30 min (Kim et al., 1995)

- $\quad$ FM, Flooding Method: $1 \mathrm{~g}$ of air dried and heat-treated samples was suspended in a flooding solution $(0.1 \%$ skim milk $0.1 \mathrm{M}$, potassium

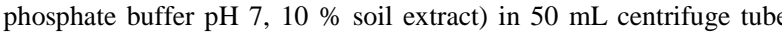
and incubated at $30^{\circ} \mathrm{C}$ for $90 \mathrm{~min}$, centrifuged at $4000 \mathrm{rpm}$ for 10 min and incubated again at $30^{\circ} \mathrm{C}$ for $30 \mathrm{~min}$ (modified from Suzuki et al., 1999)

- $\quad$ PH, Phenol treatment: $1 \mathrm{~g}$ of heat-treated samples were suspended in $1.5 \%$ phenol solution and incubated for $10 \mathrm{~min}$ at room temperature (Panthier et al., 1979).

In addition to $\mathrm{AD}$, soil free roots were subjected to separate pre-treatments:

- FD, freeze dry: freeze dried roots were rehydrated in sterile water for 3 min, cleaned using $0.1 \%$ Tween 20 (15 sec) and sterile water (1 min) twice and finally with sterile water supplemented with Terbinafin $(1 \mathrm{mg} / \mathrm{L})$ for $5 \mathrm{~min}$.
- $\quad \mathbf{A D + S}$, air dry with sterilisation: $\mathrm{AD}$ roots were rehydrated in sterile water for $3 \mathrm{~min}$ prior to gentle sterilisation using $0.1 \%$ Tween 20 (30 $\mathrm{sec}), 75 \%$ ethanol $(15 \mathrm{sec}), 1 \% \mathrm{H}_{2} \mathrm{O}_{2}(15 \mathrm{sec}), 75 \%$ ethanol $(15 \mathrm{sec})$ $0.2 \% \operatorname{SDS}(3 \mathrm{~min})$ and sterile water $(1 \mathrm{~min})$ with a final rinse using sterile water supplemented with Terbinafin $(1 \mathrm{mg} / \mathrm{L})$ for $5 \mathrm{~min}$.

Pre-treated roots were then pounded in the presence of $0.2 \%$ SDS. The slurry filtered using sterile gauze to eliminate large roots pieces and supernatant used for dilution. All treated samples were serially diluted to $10^{-2}, 10^{-3}$ and $10^{-4}$ using $0.2 \%$ SDS solution.

\section{Isolation Media}

Pre-treated sample were inoculated onto the following media, with three replicates each:

- SEA, Soil Extract Agar: $250 \mathrm{~mL}$ soil extract, $0.1 \%$ D-glucose, 0.05 $\%$ yeast extract, $0.05 \% \mathrm{~K}_{2} \mathrm{HPO}_{4}$ and $1.5 \%$ agar (modified from Hamaki et al., 2005)

- HSV, Humic Acid Vitamin Agar: humic acid $1.0 \mathrm{~g}, \mathrm{Na}_{2} \mathrm{HPO}_{4} 0.5 \mathrm{~g}$ $\mathrm{KCl} 1.7 \mathrm{~g}, \mathrm{MgSO}_{4} .7 \mathrm{H} 2 \mathrm{O} 0.05 \mathrm{~g}, \mathrm{FeSO}_{4} .7 \mathrm{H}_{2} \mathrm{O} 0.01 \mathrm{~g}, \mathrm{CaCl}_{2} .2 \mathrm{H}_{2} \mathrm{O}$ $0.735 \mathrm{~g}, \mathrm{CaCO}_{3} 0.02 \mathrm{~g}$, agar $16 \mathrm{~g}$, trace element, vitamin mixture (modified from Hayakawa and Nonomura, 1987)

- APA, Modified Arginine Vitamin Agar: L-Arginine 0.1 g, LAsparagine $0.1 \mathrm{~g}$, Glutamic acid $0.1 \mathrm{~g}$, Histidine $0.1 \mathrm{~g}$, D-glucose $0.25 \mathrm{~g}$, Glycerol $0.25 \mathrm{~g}$, Yeast extract $0.1 \mathrm{~g}, \mathrm{~N}-\mathrm{Z}$ amine $0.1 \mathrm{~g}$, $\mathrm{KH}_{2} \mathrm{PO}_{4} 50 \mathrm{mg}, \mathrm{MgSO}_{4} .7 \mathrm{H}_{2} \mathrm{O} 50 \mathrm{mg}$, Cellulose $0.5 \mathrm{~g}$, trace element $0.5 \mathrm{~mL}$, Rice extract $25 \mathrm{~mL}$, agar $15 \mathrm{~g}$, vitamin mixture $2 \mathrm{~mL}$ (modified from Shirling and Gottlied, 1966)

- REA, Rice Extract Agar: $2.5 \mathrm{~g}$ cooked rice filtrate, $\mathrm{KNO}_{3} 0.5 \mathrm{~g}$, trace element mix $0.5 \mathrm{~mL}, \mathrm{KH}_{2} \mathrm{PO}_{4} 0.1 \mathrm{~g}, \mathrm{NaCl} 0.1 \mathrm{~g}, \mathrm{Mg}_{2} \mathrm{SO} 4.7 \mathrm{H}_{2} \mathrm{O}$ $0.005 \mathrm{~g}$, yeast extract $0.005 \mathrm{~g}$, Vitamin mixture $1.0 \mathrm{~mL}$, Agar $15.0 \mathrm{~g}$

with

- Trace element mix per litre, $\mathrm{CaCl}_{2} .2 \mathrm{H}_{2} \mathrm{O} 4 \mathrm{~g}, \mathrm{ZnSO}_{4} 7 \mathrm{H}_{2} \mathrm{O} 2 \mathrm{~g}$, $\mathrm{N}_{2} \mathrm{~B}_{4} \mathrm{O}_{7} .10 \mathrm{H}_{2} \mathrm{O} 0.1 \mathrm{~g}, \mathrm{FeSO}_{4} .7 \mathrm{H}_{2} \mathrm{O} 5 \mathrm{~g}, \mathrm{KJ} 0.05 \mathrm{~g}, \mathrm{CoCl}_{2} .6 \mathrm{H}_{2} \mathrm{O} 0.5 \mathrm{~g}$, $\mathrm{CuSO}_{4} .5_{2} \mathrm{O} 0.12 \mathrm{mg}, \mathrm{MnCl}_{2} .4 \mathrm{H}_{2} \mathrm{O} 2 \mathrm{~g}, \mathrm{Na}_{2} \mathrm{MoO}_{4} .2 \mathrm{H}_{2} \mathrm{O} 0.05 \mathrm{~g}, \mathrm{H}_{2} \mathrm{SO}$ 1- $2 \mathrm{~mL}$

- Vitamin mixture per $100 \mathrm{~mL}$, p-aminobenzoic acid $50 \mathrm{mg}$, calcium pantothenate $50 \mathrm{mg}$, inositol $50 \mathrm{mg}$, niacin $50 \mathrm{mg}$, pyridoxin $\mathrm{HCl} 50 \mathrm{mg}$, riboflavin $50 \mathrm{mg}$, thiamine $\mathrm{HCl} 50 \mathrm{mg}$, biotin $25 \mathrm{mg}$, water up to100 $\mathrm{mL}$. Sterilisation by filtration.

To suppress the overgrowth of unwanted filamentous fungi and bacterial population, the isolation agar media were supplemented with $1 \mathrm{ppm}$ Terbinafin 25 ppm Nalidixic Acid, and 25 ppm Cycloheximide. Inoculated agar plates were incubated at $28{ }^{\circ} \mathrm{C}$ for 2 weeks before the total number of colonies for actinomycetes, bacteria and fungi were counted. Further incubation for up to six weeks was necessary for the isolation of slow-growing strains.

\section{Colonies Selection and Purification}

After at least two weeks of incubation, typical actinomycetes colonies that grew on isolation agar were thoroughly observed under light microscope with a 50-x long distance objective (Olympus LMPLFLN; Olympus, Tokyo, Japan) Observation and selection were based on morphological characteristics of sporeforming structures. Colonies with spore chain structures tentatively belonging to rare actinomycetes were purified onto yeast extract-malt extract agar (ISP2) (Shirling and Gottlieb, 1966) without antibiotics to obtain pure cultures.

Representatives of common genera within the family Streptomycetaceae and Micromonosporaceae were also selected and purified with severe dereplication. Sporulation and other features of purified cultures were characterised on SEA agar, while colonial morphology was observed on ISP2 agar plates. Spore chain structures and colonial morphology were recorded in a database and photo documented.

\section{Actinomycetes Identification}

Preliminary identification of pure cultures was based on morphological observations, mainly sporulation type, presence of aerial mycelium and hyphae fragmentation, allowing a tentative assignment to a family or a genus (Shirling and Gottlieb, 1966; Cross, 1989; Bergey's Manual, 2012). Obvious duplicates from one subsample were eliminated. The colonies on SEA were directly observed using $50 \mathrm{x}$ long distance objective (Olympus LMPLFLN; Olympus, Tokyo, Japan), further identification was conducted using molecular methods.

DNA was obtained by the "freeze-thaw" modified method by Muramatsu et al. 2003. Master mix $(30 \mu \mathrm{l})$ containing $2 \mu \mathrm{l}$ of the DNA extract, $20 \mathrm{mM}$ each primer SRR181F (5"e- GTT TGA TCC TGG CTC AGG AC - $3^{\mathrm{ec}}$ ) and SRR182R (5"e-GGT GTT CCT CMH GAT ATC TG - 3"e), $10 \mathrm{mM}$ dNTP, 10 x buffer (without $\mathrm{MgCl}_{2}$ ) and 1 Unit Taq DNA polymerase (New England Biolabs) was used to amplify the $16 \mathrm{~S}$ rRNA genes with the following parameters: $1 \mathrm{~min}$ at 
$96{ }^{\circ} \mathrm{C}, 30$ cycles of $45 \mathrm{sec}$ at $96{ }^{\circ} \mathrm{C}, 1 \mathrm{~min}$ at $53{ }^{\circ} \mathrm{C}, 2 \mathrm{~min}$ at $72{ }^{\circ} \mathrm{C}$ and the final annealing for $7 \mathrm{~min}$ at $72{ }^{\circ} \mathrm{C}$. Amplified products were purified (GFX PCR DNA GE Healthcare) and sequenced with primer pair SRR178F ( $5^{\circ{ }^{\circ e}}$ - GAA CGC TGG CGG CGT GCT $-3^{\circ \circ}$ ) \& SRR192R' (5"- GCA TTY CAC CGC TAC ACC - $\left.3^{\circ \circ}\right)$ using BigDye ${ }^{\circledR}$ Terminator v3.1 Cycle Sequencing Kits based on Sanger's dideoxy sequencing method.

\section{Phylogenetic Clustering}

Phylogenetic trees were then constructed for each genus based on the 16S rRNA identification. Sequence alignment was done using BioEdit (Hall, 1999). Phylogenetic and molecular evolutionary analyses were conducted using MEGA version 5 (Tamura et al., 2011). The evolutionary history was inferred using the Neighbour-Joining method (Saitaou and Nei, 1987). The evolutionary distances were computed using the Maximum Composite Likelihood method (Tamura $e$ al., 2004). For genera with only one strain or one cluster, phylogenetic trees were constructed by adding in sequences from the top 10 16S rRNA BLAST results. This is to ensure that the isolated strain clusters within the identified genus.

\section{Ranking}

Sequence-similarity search for all sequences were done using BLAST programme against 16S rRNA database from GenBank (Benson et al., 2012). Taxonomic positions of the strains were made based on the maximum identity (MI) score. Individual strains were assigned into one of the five categories below:

\begin{tabular}{lcc}
\hline Category & $\begin{array}{c}\text { Blast homology } \\
(\text { MI) }\end{array}$ & Taxonomic Position \\
\hline Category 1 & $96.9 \%$ and below & Novel genus \\
\hline Category 2 & $97-98.65 \%$ & Novel species \\
\hline Category 3 & $98.7-99.5 \%$ & Putative novel species \\
\hline Category 4 & $99.6-99.8 \%$ & Putative known species \\
\hline Category $\mathbf{5}$ & $99.9 \%$ and above & $\begin{array}{c}\text { Identical or closely related } \\
\text { species }\end{array}$ \\
\hline
\end{tabular}

\section{RESULTS AND DISCUSSION}

All 578 sequences were deposited in Genbank (KY052189 - KY052766). In this study, the results are only tendencies as the number of strains isolated was limited. In vitro cultivation covers about 0.1 to $10 \%$ of total soil microbiota (Kell et al., 1998; Torsvik and Ovreas, 2002).

\section{Phylogenetic Clustering}

Overall, 159 distinct phylogenetic clusters or TU from the total of 578 strain were delineated. Micromonospora, having the highest number of strain isolated (257 strains) were represented by $40 \mathrm{TU}$ similar with Streptomyces (120 strains, $40 \mathrm{TU})$. An average of 6 strains per TU were selected for Micromonospora, compared to Streptomyces with average of 3 strains per TU. Analytical approach using TU effectively eliminate over-representation of strains. Streptacidiphilus, Mycobacterium and Dactylosporangium showed highest species diversity with the average number of strains per TU of $1.17,1.20$ and 1.30 , respectively. This was not taking into account genus with only one representative species or strain isolated. Figure 1 shows phylogenetic clusters of strains within a genus Actinoallumurus while Figure 2 shows phylogenetic position of a strain with top 10 blast result.

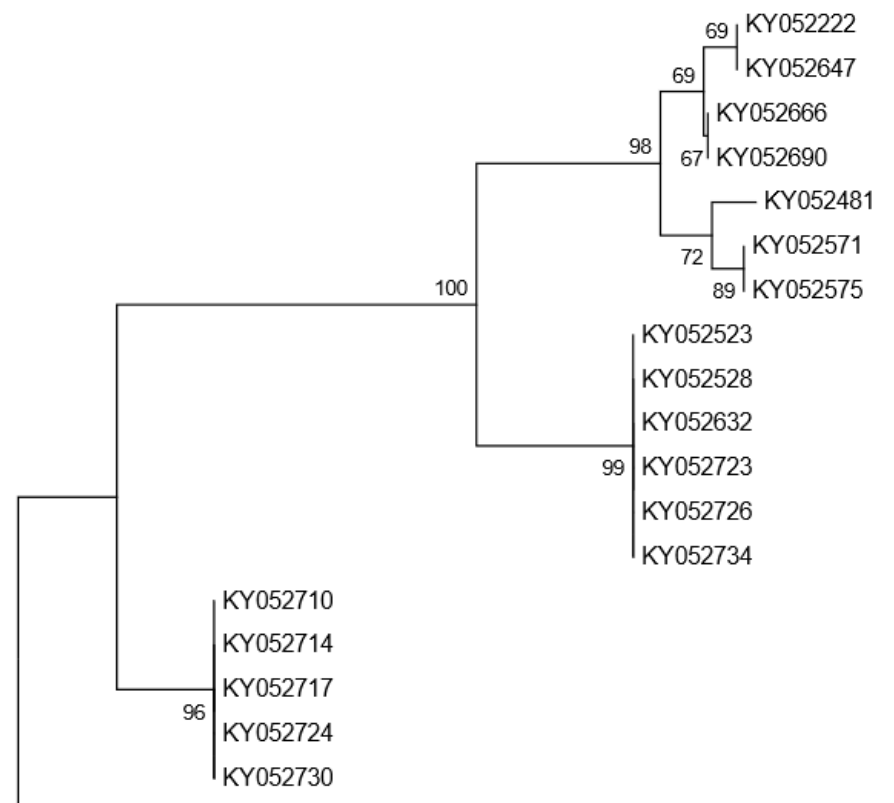

KY052212

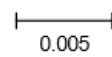

Figure 1 Phylogenetic tree of all strains isolated by under the genera Actinoallumurus

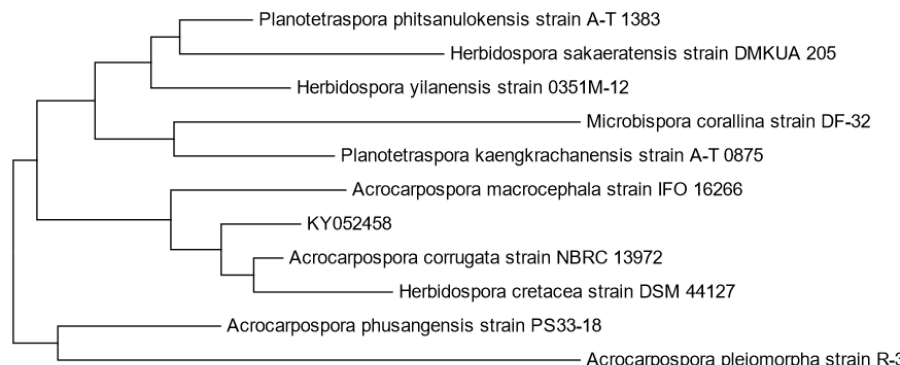

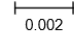

Figure 2 Phylogenetic tree for strain KY052458 (Acrocarpospora sp.) with sequences from top $1016 \mathrm{~S}$ rRNA database

\section{Ranking}

For this project, TU were divided into five categories based on their $16 \mathrm{~S}$ sequencing and phylogenetic analysis (see Table 1).

Table 1 Taxonomic unit by Ranking and Category

\begin{tabular}{|c|c|c|c|c|c|c|c|c|c|c|c|c|}
\hline \multirow[t]{2}{*}{ No. } & \multirow[t]{2}{*}{ Family } & \multirow[t]{2}{*}{ Genus } & \multirow{2}{*}{$\begin{array}{l}\text { No. of } \\
\text { strains }\end{array}$} & \multirow[t]{2}{*}{ TU } & \multirow[t]{2}{*}{ TU\% } & \multirow[t]{2}{*}{ Category } & \multicolumn{6}{|c|}{ No. of TU/Category } \\
\hline & & & & & & & 1 & 2 & 3 & 4 & 5 & TOTAL \\
\hline 1 & Micromonosporaceae & Micromonospora & 257 & 40 & 25 & $\begin{array}{l}\text { C1, C3, } \\
\text { C4, C5 }\end{array}$ & 1 & 0 & 11 & 20 & 8 & 40 \\
\hline 2 & & Dactylosporangium & 13 & 10 & 6 & $\begin{array}{l}\mathrm{C} 2, \mathrm{C} 3, \\
\mathrm{C} 4, \mathrm{C} 5\end{array}$ & 0 & 1 & 1 & 6 & 2 & 10 \\
\hline 3 & & Planosporangium & 8 & 3 & 2 & $\mathrm{C} 3, \mathrm{C} 4$ & 0 & 0 & 1 & 2 & 0 & 3 \\
\hline 4 & & Verrucosispora & 1 & 1 & 1 & $\mathrm{C} 3$ & 0 & 0 & 1 & 0 & 0 & 1 \\
\hline 5 & & Polymorphospora & 1 & 1 & 1 & $\mathrm{C} 2$ & 0 & 1 & 0 & 0 & 0 & 1 \\
\hline 6 & Streptomycetaceae & Streptomyces & 120 & 40 & 25 & $\begin{array}{l}\mathrm{C} 2, \mathrm{C} 3, \\
\mathrm{C} 4, \mathrm{C} 5\end{array}$ & 0 & 3 & 12 & 14 & 11 & 40 \\
\hline 7 & & Streptacidiphilus & 7 & 6 & 4 & $\begin{array}{c}\mathrm{C} 3, \mathrm{C} 4, \\
\mathrm{C} 5\end{array}$ & 0 & 0 & 2 & 3 & 1 & 6 \\
\hline 8 & & Kitasotospora & 2 & 2 & 1 & $\mathrm{C} 2, \mathrm{C} 5$ & 0 & 1 & 0 & 0 & 1 & 2 \\
\hline 9 & Streptosporangiaceae & Astrosporangium & 1 & 1 & 1 & $\mathrm{C} 2$ & 0 & 1 & 0 & 0 & 0 & 1 \\
\hline 10 & & Planotetraspora & 3 & 1 & 1 & $\mathrm{C} 5$ & 0 & 0 & 0 & 0 & 1 & 1 \\
\hline 11 & & Streptosporangium & 17 & 5 & 3 & $\begin{array}{c}\mathrm{C} 3, \mathrm{C} 4, \\
\mathrm{C} 5\end{array}$ & 0 & 0 & 1 & 2 & 2 & 5 \\
\hline 12 & & Nonoтиraea & 12 & 3 & 2 & $\begin{array}{c}\mathrm{C} 1, \mathrm{C} 4, \\
\mathrm{C} 5\end{array}$ & 1 & 0 & 0 & 1 & 1 & 3 \\
\hline 13 & & Microtetraspora & 8 & 1 & 1 & C5 & 0 & 0 & 0 & 0 & 1 & 1 \\
\hline
\end{tabular}




\begin{tabular}{|c|c|c|c|c|c|c|c|c|c|c|c|c|}
\hline 14 & & Microbispora & 35 & 5 & 3 & $\begin{array}{c}\text { C3, C4, } \\
\text { C5 }\end{array}$ & 0 & 0 & 1 & 3 & 1 & 5 \\
\hline 15 & & Sphaerisporangium & 19 & 9 & 6 & $\begin{array}{c}\mathrm{C} 1, \mathrm{C} 2, \\
\mathrm{C} 3\end{array}$ & 1 & 7 & 1 & 0 & 0 & 9 \\
\hline 16 & & Acrocarpospora & 1 & 1 & 1 & C5 & 0 & 0 & 0 & 0 & 1 & 1 \\
\hline 17 & Nocardioidaceae & Nocardia & 41 & 12 & 8 & $\begin{array}{l}\mathrm{C} 2, \mathrm{C} 3, \\
\mathrm{C} 4, \mathrm{C} 5\end{array}$ & 0 & 1 & 3 & 5 & 3 & 12 \\
\hline 18 & Thermomonosporaceae & Actinoallomurus & 19 & 7 & 4 & $\begin{array}{l}\mathrm{C} 1, \mathrm{C} 2, \\
\mathrm{C} 3, \mathrm{C} 4\end{array}$ & 1 & 3 & 2 & 1 & 0 & 7 \\
\hline 19 & & Actinomadura & 1 & 1 & 1 & $\mathrm{C} 4$ & 0 & 0 & 0 & 1 & 0 & 1 \\
\hline 20 & Mycobacteriaceae & Mycobacterium & 6 & 5 & 3 & $\mathrm{C} 2, \mathrm{C} 5$ & 0 & 4 & 0 & 0 & 1 & 5 \\
\hline 21 & Tsukamurellaceae & Tsukamurella & 3 & 1 & 1 & $\mathrm{C} 5$ & 0 & 0 & 0 & 0 & 1 & 1 \\
\hline 22 & Geodermatophilaceae & Blastococcus & 1 & 1 & 1 & $\mathrm{C} 2$ & 0 & 1 & 0 & 0 & 0 & 1 \\
\hline 23 & Micrococcaceae & Kocuria & 1 & 1 & 1 & $\mathrm{C} 5$ & 0 & 0 & 0 & 0 & 1 & 1 \\
\hline \multirow[t]{2}{*}{24} & Thermoactinomycetaceae & Shimazuella & 1 & 1 & 1 & $\mathrm{C} 3$ & 0 & 0 & 1 & 0 & 0 & 1 \\
\hline & & Subtotal & 578 & 158 & 100 & & 4 & 23 & 37 & 58 & 36 & 158 \\
\hline
\end{tabular}

Legend: TU -Taxonomic unit, C - Category

\section{Novel Species or Genus}

Under Category 1 or blast homology below $97 \%$, the strains can be considered as novel genus. Four TU were identified as Micromonospora (96.4\% MI), Nonomuraea (96.6 \% $\quad$ MI), Sphaerisporangium (96.98 \% $\quad$ MI) and "Actinoallomurus" (92.8 \% MI), with one strain each except for Sphaerisporangium that has two strains. The strain with a very low blast homology value probably belongs to a novel genus.

\section{Novel Species and Putative Novel Species}

For Category 2 and 3, strains cannot be assigned to a validated species as the blast homologies are lower than $99 \%$ (Stackebrandt and Ebers, 2006), but higher than $97 \%$. A main percentage of the strains (60 TU or $38 \%$ of TU) are under this category. There were $23 \mathrm{TU}$ and $37 \mathrm{TU}$ under Category 2 and 3 respectively. For Category 2, majority of the TU (7 TU or $30.4 \%$ ) belongs to the genus Sphaerisporangium while in Category 3, most of the strains were from the genera Streptomyces (12 TU or $32.4 \%$ ) and Micromonospora (11 TU or $29.7 \%$ ). Novel species or putative novel species were found in 17 genera, comprising all genera that were isolated under the family Micromonosporaceae and Streptomycetaceae.

\section{Known Species}

There were $58 \mathrm{TU}$ for Category 4 and $36 \mathrm{TU}$ for Category 5 that could be assigned to a validated species. Under Category 4 (putative known species), there are possibly some novel species however, further test is required to define their taxonomic position. Category 5 are found in 13 genera, among which 5 genera contains only one TU each. TU assigned to a validated species under Category 5 represents only $22.6 \%$ of the total.

A high level of novel species was observed: $64 \mathrm{TU}$ among 158 corresponding to $40.5 \%$. In addition, among strains with over $99 \%$ similarity but less than 99.8 $\%$, a part can belong to novel species due mainly to another origin than the related, described species. Very recently diverged species may not be recognizable (Fox et al., 1992). Various strains with a coefficient of similarity higher than $99 \%$ could be classified as novel species after delineation by other characters e.g. a species has to be defined by a series of phenotypic characters in a polyphasic approach including chemotaxonomy and DNA-DNA relatedness evaluation (Tindall et al., 2010)

\section{Soil community structure}

Reports states that in normal and healthy soil, the density of actinomycetes in population about $10^{6}-10^{7} \mathrm{cfu}^{-1}$ soil (Goodfellow and Williams, 1983; Labeda, 1990; Celentis Analytical, 2003; Handayanto and Hairiah, 2007) as quantified by dilution plate counts. The reported total actinomycetes counts for paddy samples ranged from 1 to $3 \times 10^{6} \mathrm{cfu} \mathrm{g}^{-1}$ soil (Xu et al., 1996; Saranraj et al., 2013).

In the wetland paddy soil samples, the actinomycetes density was lower $(6.84 x$ $10^{5} \mathrm{cfu} \mathrm{g}^{-1}$ soil). Soil water content is closely associated with nutrient availability, as well as with soil aeration affecting the soil microbial community in combination (Griffin, 1981; Uhlirova, 2005). For hill paddy soil, the populations were slightly higher $\left(1.61 \times 10^{6} \mathrm{cfu} \mathrm{g}^{-1}\right.$ soil $)$ as actinomycetes favour drier conditions due to their filamentous structure (Waksman, 1959; Alexander, 1961; Potts, 1994). Total colony count (TCC) among samples differ during the warm season, slightly lower for wet paddy while highest for hill paddy (see Figure 3).

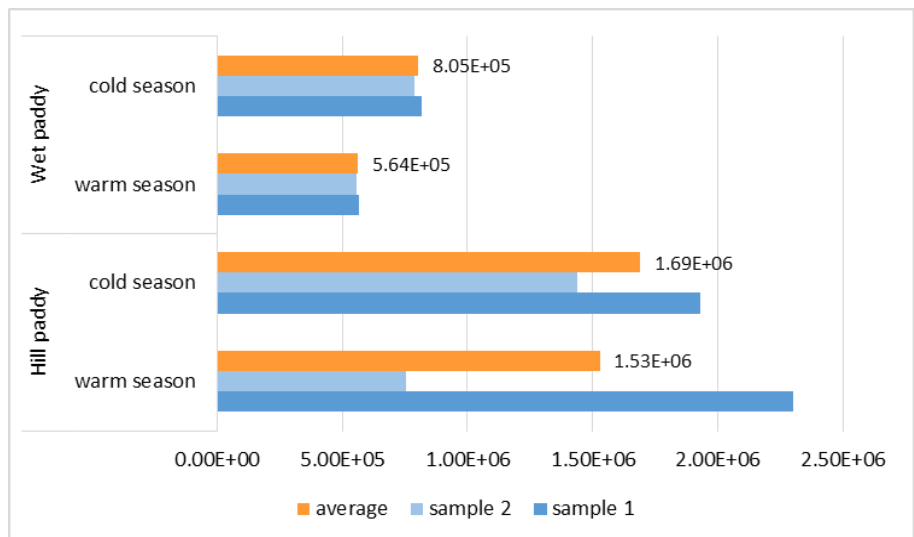

Figure 3 Actinomycetes Total Colony Count (TCC) based on sample type and season

\section{Paddy Field Environment}

Majority of the strains (44\%) isolated in this study belonged to the genus Micromonospora (40 TU). Ten TU and $5 \mathrm{TU}$ were exclusive for wetland and hill paddy respectively. Various reports indicated that strains of Micromonospora are the dominant actinomycetes from aquatic environment (Eccleston et al., 2008; Gebreyohannes et al., 2013). The majority of the strains isolated (111 TU) were dependent on the location. Eleven genera were observed only in either one of the locations. Out of the 24 genera, 10 genera $(30 \%, 48 \mathrm{TU})$ were observed in both paddy environments, mainly from Micromonospora (16\%,25 TU), followed by Streptomyces $(6 \%, 10 \mathrm{TU})$ and Nocardia $(3 \%, 4 \mathrm{TU})$. Under Category 1 (novel genus) three TU were identified from hill paddy and one TU from wet paddy respectively.

\section{Effects of Seasonal Change}

As with vegetation, microbial community structure is most influenced by soil temperature and moisture (Sylvia $\boldsymbol{e}$ t al., 2005). Major differences are again observed in the total number of TU exclusively isolated during one season, 71 $\mathrm{TU}$ in cool season and 39 in warm season. High number of TU in the cool season indicates a higher diversity among the isolated strains (45\% non-redundant). TU exclusive by season were members from genera Dactylosporangium, Streptacidiphilus, Mycobacterium and Kitasatospora. Only a total of 49 TU (31 $\%$ from 11 genera) have members isolated from both cool and dry season. Representatives of the genus Micromonospora seems are well represented in both seasons. Three TU identified from cool season and one TU from warm season belong to under Category 1 (novel genus).

\section{Strains from rhizosphere and roots}

Representatives of 12 genera (17 TU) were isolated from rhizosphere and 9 genera (11 TU) from roots. Additional two genera could be detected, Polymorphospora and Verrucosispora, isolated from rhizospheric soil and root samples respectively. Eleven TU distributed among five genera were exclusive for root samples. Majority of the endophytes observed were Micromonospora (61 $\%$ ) followed by Streptomyces (16\%). The high occurrence of endophytic Micromonospora isolated in this study also corresponds to a study made by Trujillo and her colleagues (2014) where they discovered that Micromonospora populations are potential plant growth promoters. The influence of Micromonospora on rice should be evaluated.

Among the isolated strains, one strain is categorised as a novel species (BLAST homology $96.98 \%$ ) in the genus Sphaerisporangium while two strains were 
identified as novel species (Category 2 - 97.35\% and 97.74\%) Sphaerisporangium and Streptomyces respectively. Diversity and exclusiveness of strains were not significant for endophytes isolated in this study.

\section{Distribution of Actinomycetes Isolated}

114 TU $(64 \%)$ were exclusive to one type of sample, with a majority exclusive to soil samples (85 TU), followed by rhizospheric (17 TU) and root (11 TU) samples. The overlapping's were minimal. Highest TU overlapping was observed for the genus Micromonospora (21 TU, $13 \%$ ), followed by Streptomyces (6 TU, $4 \%$ ) and Actinoallumurus (3 TU, $2 \%$ ). This highlights the importance of diversifying the sample source for isolation.

\section{Pre-treatment of the Samples}

Most isolates were obtained from AD (89 TU), followed by HT (76 TU), PH (42 TU), and FM (37 TU). AD root samples (15 TU) and FD method (14 TU) gave satisfactory results. Nineteen genera were isolated using AD alone, whereby 5 genera were exclusively isolated by this method (Kitasatospora, Blastococcus, Kocuria, Shimazuella, and Verrucosispora). Other exclusive genera by pretreatment are Microtetraspora, Astrosporangium and Polymorphospora for HT and, Acrocarpospora and Actinomadura for PH. AD pre-treatment gave the highest number of actinomycetes $\left(3.65 \times 10^{6} \mathrm{cfu} \mathrm{g}^{-1}\right.$ soil). Thirty-four TU was exclusively isolated from air dry treatment with the highest TU, 12 from Streptomyces.

Twenty-nine exclusive TU were isolated from HT followed by FM (12 TU), PH (7 TU), AD+S (4 TU) and FD (2 TU). The goal of the flooding (FM) method is to increase the percentage of motile actinomycetes. However, in this study only 4 motile genera (Dactylosporangium, Microtetraspora, Planotetraspora and Actinoallumurus) were isolated using other pre-treatment methods. Improvemen on the current FM treatment will be needed to isolate more motile actinomycetes.

\section{Isolation Media}

Both HSV (humic acid as carbon and nitrogen source) and SEA (soil extract) media stimulated the differentiation of actinomycetes and allows direct microscopical observations. Most of the strains (178 TU) were isolated from such agar-plates. APA medium contains a mixture of nitrogen, carbon sources, vitamins and minerals; 86 strains (48 TU) have been isolated from this medium. Lastly, on REA medium, made from rice extract designed especially for this study, only 9 strains were isolated but with very low duplication (7 TU). Most genera were isolated from HSV media, 18 genera out of 21 genera, followed by SEA, 16 genera, APA 10 genera and REA three genera.

\section{Soil Analysis}

No significant variations were observed among paddy field types and season except for soil colour, moisture content, total organic content and exchangeable magnesium season (see Table 3). Available phosphorus was only detected in one sample for hill paddy field during the cold. Mardi (2000) has reported that the optimum soil chemical properties for paddy growth requirement are $\mathrm{pH} 5.5-6.0$, organic carbon $(2-3 \%)$, available $\mathrm{P}\left(>40 \mathrm{mg} \mathrm{kg}^{-1}\right)$ and $\mathrm{ExK}\left(>0.1+\mathrm{cmol} \mathrm{kg}^{-1}\right)$ (Aishah et al., 2010). Soil moisture content for wetland paddy is almost double the value then for hill paddy. Hill paddy moisture content during the dry season is slightly higher than during the cool season. The acidity of soil samples ranged from $\mathrm{pH}$ 5.0-5.4. Acidic nature of Malaysian paddy soils have also been observed by other researchers (Arnott, 1964; Kawaguch and Kyuma, 1974). Organic matter can reach very high levels in soils that are usually waterlogged; such soils often smell sour and are oily (Plaster, 2002). TOC in both paddy environments ranged from two to seven percent. High CEC values for soil indicates higher capability of retaining nutrient therefore having better soil properties. As most soils used in plant production have a cation exchange capacity (CEC) between five and 30 (Kawaguch and Kyuma, 1974), the paddy soils collected with CEC values of 20 are of medium value, good quality for agriculture (Hill Laboratories, nd). Phosphorus is considered the prime limiting factor on plant growth in many areas, because it is the least mobile and available essential nutrient in soil (Hinsinger, 2001). Only soil sample from hill paddy during the cold season showed sufficient levels of available P (>10 mg kg-1) (Kamprath and Watson, 1980).

Table 3 Soil analysis for wetland and hill paddy soil samples

\begin{tabular}{|c|c|c|c|c|c|c|c|c|c|c|c|}
\hline \multirow{2}{*}{ Location } & \multirow{2}{*}{$\begin{array}{l}\text { Alt } \\
\text { (ft) }\end{array}$} & \multirow{2}{*}{ Season } & \multirow{2}{*}{$\mathbf{p H}$} & \multirow{2}{*}{$\operatorname{MC}(\%)$} & \multirow{2}{*}{$\begin{array}{c}\text { CEC } \\
(+\mathrm{cmol} / \mathrm{kg})\end{array}$} & \multirow{2}{*}{$\begin{array}{c}\text { TOC } \\
(\%)\end{array}$} & \multicolumn{4}{|c|}{ Exchangeable Ions (+cmol/ kg) } & \multirow{2}{*}{$\begin{array}{c}\text { Avail. } \\
\mathbf{P}\end{array}$} \\
\hline & & & & & & & $\mathbf{C a}$ & $\mathrm{Mg}$ & $\mathbf{K}$ & $\mathrm{Na}$ & \\
\hline Wetland paddy & & Cold & 5.4 & 52 & 19.08 & 7.28 & 3.4 & 0.51 & 0.13 & 0.1 & 0 \\
\hline $\begin{array}{l}\text { Kpg Jenan, Serian } \\
\text { N01' 08.880" } \\
\text { E110'29.053" }\end{array}$ & 90 & Warm & 5.0 & 44 & 20.56 & 4.23 & 2.96 & 0.4 & 0.11 & 0.006 & 0 \\
\hline Hill paddy field & & Cold & 5.2 & 27 & 17.3 & 2.65 & 3.28 & 1.34 & 0.17 & 0.003 & 19 \\
\hline $\begin{array}{l}\text { Kpg Payang, } \\
\text { Padawan } \\
\text { N01' 13.248" } \\
\text { E110' } 18.680 "\end{array}$ & 312 & Warm & 5.3 & 30 & 16.96 & 3.17 & 3.85 & 1.41 & 0.21 & 0.003 & 0 \\
\hline
\end{tabular}

Legend: Alt - Altitude, MC - Moisture Content, CEC - Cation Exchange Capacity, TOC - Total Organic Content

\section{CONCLUSION}

The results of this project demonstrate the potential of Sarawak for the discovery of novel actinobacteria species. The strategy followed in this study allowed the isolation and selection strains belonging to 24 genera with the percentage of novel and putative novel species is over $40 \%$, and thus high. This demonstrates that man-managed environments have a good diversity of microbial strains leaving a huge genetic pool yet to be discovered. The pre-treatments of the environmental samples and the media used should be extended in order to increase the diversity of the strains isolated. Horizontal gene transfer of up to 30$35 \%$ especially in the accessory genome, results in organisms belonging to the same species with contrasting phenotypes and/or ecological potential (Luo et al. 2011). Strains within a species can be grouped by some independent specific characteristics; as biochemical, physiochemical, serological or pathological properties (biovars, biotypes, serovars, pathovars) can overlap each other (Rosselló-Móra and Amann, 2001). Additional unambiguous characters are necessary for accurate strain identification; the methods should be robust, inexpensive and not tedious. With advancement of technologies, a shift from evolutionary studies of rRNA genes to microbiome study is becoming more apparent. Massively parallel high throughput sequencing technologies, to pyrosequencing and now MISEQ and HISEQ has allowed us to interrogate the microbial composition of biological samples at a cheaper and unprecedented resolution (Mizrahi-Man et al., 2013). Approaches will be continually improved to diversify the Natural Product Library for bioprospecting by exploring-various ecosystems. The strategy should be improved by evaluating the actinomycete diversity by culture-independent methods, including metagenomic (Rondon et al., 2000)
Acknowledgments: We would like to thank all those involved in the Microbe Natural Product Library in Sarawak Biodiversity Centre and the paddy fields owner Mr. Frankie Kumbak for allowing us to collect samples and providing us with the relevant information. We would also like to thank Miss Elizabeth Ting Jen Yi for her work contribution and the Molecular group for sequencing the isolated strains especially Miss Arzie Ramli.

\section{REFERENCES}

Adegboye, M.F., Babalola, O.O. (2012). Taxonomy and ecology of antibiotic producing actinomycetes. African Journal of Agricultural Research 7(15):22552261

https://pdfs.semanticscholar.org/8abc/05491a40ad0f0f76511ee6600486723aa703 .pdf

Aishah, A.W., Zauyah, S., Anuar, A.R., Fauziah, C.I. (2010). Spatial Variability of Selected Chemical Characteristics of Paddy Soils in Sawah Sempadan, Selangor, Malaysia. Malaysian Journal of Soil Science 14:27-39.

Alexander, M. (1961). Introduction to Soil Microbiology. London: John Wiley and Sons.

Arnott, G.W.A. (1964). Tentative Guide to the Interpretation of Some Chemical Analyses of Malayan Soils (mimeographed), Information

Paper No. 246, Division of Agriculture, Ministry of Agriculture and Cooperatives, Kuala Lumpur.

Benson, D.A., Karsch-Mizrachi, I., Clark, K. et al. (2012). GenBank Nucleic Acids Res. 40:48-53. https://doi.org/10.1093/nar/gks1195

Bergey's Manual. Bergey's Manual of Systematic bacteriology, Second edition. Volume 5, The Actinobacteria, Part A and B. Springer, 2012. 
Bray, R.H., Kurtz, L.T. (1945). Determination of total, organic, and available forms of phosphorus in soils. Soil Science 59:39-45.

Bredholt, H., Fjearvik, E., John, G., Zotchev, S.B. (2008). Actinomycetes from the sediments in the Trondheim Fjord, Norway: Diversity and Biological Activity. Mar. Drugs 6(1):12-24. PMCID: PMC2474955.

Burck, I.C., Yonker, C.M., Parton, W.J. et al. (1989). Texture, climate, and cultivation effects on soil organic matter content in USA grassland soils. Journal of Soil Science Society of America 53:800-805. Celentis Analytical (2003). Biological soil test-definition.

Chankhamhaengdecha, S., Hongvijit, S., Srichaisupakit, A. et al. (2013). Endophytic Actinomycetes: A Novel Source of Potential Acyl Homoserine Lactone Degrading Enzymes. BioMed Research International. https://dx.doi.org/10.1155/2013/782847

Compant, S., Clément, C., Sessitsch, A. (2010). Plant growth-promoting bacteria in the rhizo- and endosphere of plants: Their role, colonization, mechanisms involved and prospects for utilization. Soil Biol. Biochem. 42:669-678.

Cross, T. (1989). Growth and examination of actinomycetes-some guidelines. In Bergey's Manual of Systematic Bacteriology Vol. 4 (eds)

Williams, S.T., Sharpe, M.E. and Holt, J.P. pp. 2340-2343. Baltimore: Williams \& Wilkins.

Ding, L., Su, J., Xu, H., Jia, Z., Zhu, Y. (2014). Long-term nitrogen fertilization of paddy soil shifts iron-reducing microbial community revealed by $\mathrm{RNA}-{ }^{13} \mathrm{C}$ acetate probing coupled with pyrosequencing. ISME Journal. DOA, Department of Agriculture Peninsular Malaysia. Paddy Statistics of Malaysia 2011.

Doi, T., Abe, J., Shiotsu, F., Morita, S. (2010). Study on rhizosphere bacteria community in lowland rice grown with organic fertilizers by using PCR denaturing gradient gel electrophoresis. Plant Root Journal.

Dominick, D., Latif, M.T., Juahir, H. et al. (2012). An assessment of influence of meteorological factors on $\mathrm{PM}_{10}$ and $\mathrm{NO}_{2}$ at selected stations in Malaysia. Sustain. Environ. Res. 22(5):305-315.

Eccleston, G.P., Brooks, P.R., Kurtböke, D.I. (2008). The Occurrence of Bioactive Micromonosporae in Aquatic Habitats of the Sunshine Coast in Australia. Mar Drugs. Mar 6(2): 243-261. https://doi.org/10.3390/md6020243

Elliot, L.F., Lynch, J.M. (1995). The International Workshop on Establishment of Microbial Inocula in Soils: Cooperative Research Project on Biological Resource Management of the Organization for Economic Cooperation and Development (OECD). American Journal of Alternative Agriculture 10: 50-73. DOI: https://dx.doi.org/10.1017/S0889189300006160

Ellis, B., Foth, H. (1996). Soil Fertility, Second Edition. CRC Press, Technology \& Engineering.

Fox, G.E., Wisotzkey, J.D., Jurtshuk, P. Jr. (1992). How close is close: 16S rRNA sequence identity may not be sufficient to guarantee species identity. Int $J$ Syst Bacteriol 42:166-170.

Gandaseca, S., Rosli N., Pazi, A.M.M., Arianto, C.I. (2014). Effects of land use on river water quality of Awat-Awat Lawas Mangrove Forest

Limbang Sarawak Malaysia. International Journal of Physical Sciences 9(17):386-396. https://academicjournals.org/journal/IJPS/article-full-text-

pdf/F6DC7E347688

Gangwar, M., Rani, S. and Sharma, N. (2012). Investigating endophytic actinomycetes diversity from Rice for plant growth promoting and antifungal activity. IJALS. E-ISSN : 2277 - 758X, P-ISSN : 2320 - 1827.

Gavrish, E., Bollmann, A., Epstein, S., Lewis, K. (2008). A trap for in situ cultivation of filamentous actinobacteria. J Microbial Methods 72(3):257-262 https://doi.org/10.1016/j.mimet.2007.12.009

Gebreyohannes, G., Moges, F., Sahile, S., Raja, N. (2013). Isolation and characterization of potential antibiotic producing actinomycetes from water and sediments of Lake Tana, Ethiopia. Asian Pac J Trop Biomed. 3(6):426-435. https://doi.org/10.1016/S2221-1691(13)60092-1

Genilloud, O., González, I., Salazar, O., Martín, J., Tormo, J.R., Vicente, F. (2011). Current approaches to exploit actinomycetes as a source of novel natural products. J Ind Microbiol Biotechol. 38: 375-389.

https://doi.org/10.1007/s10295-010-0882-7

Gevers, D., Cohan, F.M., Lawrence, J.G. et al. (2005). Opinion: Re-evaluating prokaryotic species. Nature Reviews Microbiology. 2005;3(9):733-9.

Girvan, M.S., Bullimore, J., Ball, A.S. et al. (2004). Responses of active bacteria and fungal communities in soils under winter wheat to different fertilizer and pesticide regimens, Applied and Environmental Microbiology, 2004; 70(5):26922701.

Goodfellow, M., Williams, S.T. (1983). Ecology of actinomycetes. Annual Review of Microbiology 1983;37:189-216. https://doi.org/10.1146/annurev.mi.37.100183.001201

Griffin, D.M. (1981). Water and microbial stress. Adv.Microb.Ecol. 5:91-136. Hall, T.A. (1999). BioEdit: a user-friendly biological sequence alignment editor and analysis program for Windows 95/98/NT. Nucl. Acids. Symp. Ser. 41:95-98.

Hamaki, T., Suzuki, M., Fudou, R. et al. (2005). Isolation of Novel Bacteria and Actinomycetes using Soil-Extract Medium. Journal of Bioscience and Bioengineering 2005;99:485-492.

Handayanto, E., Hairiah, K. (2007). Soil biology: The fundamental of soil health Pustaka Adipura, Yogyakarta, Indonesia.
Hayakawa, M., Nonomura, H. (1987). Humic Acid-Vitamin Agar (HVA), a new medium for the selective isolation of soil Actinomycetes.

Technol. 65:501-509. https://doi.org/10.1016/0385-6380(87)90108-7

Hill Laboratories (nd). Technical notes. Soil test and Interpretation. Hinsinger, P. Bioavailability of soil inorganic $\mathrm{P}$ in the rhizosphere as affected by root-induced chemical changes: a review. Plant Soil 2001; 237(2):173-195.

Indananda, C., Matsumoto, A., Inahashi, Y. et al. (2010). Actinophytocola oryzae gen. nov., sp. nov., isolated from the roots of Thai glutinous

rice plants, a new member of the family Pseudonocardiaceae IJSEM 60(5):11416. https://dx.doi.org/10.1099/ijs.0.008417-0

Indananda, C., Thamchaipenet, A., Matsumoto, A., Inahashi, Y., Duangmal, K., Takahashi, Y. (2011). Actinoallomurus oryzae sp. nov., an endophytic actinomycete isolated from roots of a Thai jasmine rice plant. IJSEM Apr; 61(4):737-41. https://dx.doi.org/10.1099/ijs.0.022509-0

Inderiati, S., Franco, C.M.M. (2008). Isolation and Identification of Endophytic Actinomycetes and their Antifungal Activity. Journal of Biotechnology Research in Tropical Region 1: 1979-9756.

Jangid, K., Williams, M.A., Franzluebbers, A.J. et al. (2008). Relative impacts of land-use, management intensity and fertilization upon soil microbial community structure in agricultural systems. Soil Biol Biochem 40: 2843-2853. https://dx.doi.org/10.1016/i.soilbio.2008.07.030

Joseph, B., Priya, R.M. (2011). Bioactive Compounds from Endophytes and their Potential in Pharmaceutical Effect: A Review. American Journal of Biochemistr and Molecular Biology 1:291-309. http://dx.doi.org/10.3923/ajbmb.2011.291.309 Joshi, S.K. (2002). Rice field work and the occupational hazards. Lecturer, Dept of Community Medicine, KMCTH JKMC 4:111-114.

Kageyama, A., Matsumoto, A., Omura, S.,Takahashi, Y. (2008). Humibacillus xanthopallidus gen. nov., sp. nov. IJSEM 58:1547-1551.

https://doi.org/10.1099/ijs.0.65042-0

Kageyama, A., Takahashi, Y., Omura S.. Humihabitans oryzae gen. nov., sp. nov. IJSEM 2007;57:2163-2166.

Kageyama, A, Takahashi, Y, Seki T et al.. (2005). Oryzihumus leptocrescens gen. nov., sp. nov. IJSEM 55(6):2555-9.

Kamparth, E.J., Watson, M.E. (1980). Conventional soil and tissue tests for accessing the phosphorus status of soil. In: The role of phosphorus in agriculture American Society of Agronomy 1980;16:433-469.

Kawaguch, K., Kyuma, K. (1974). Paddy Soils in Tropical Asia, Part 1. Description of Fertility Characteristics Southeast Asian Studies.

Kazutake, K. (2007). Ecological Sustainability of the Paddy Soil-Rice System in Asia, Report of the Food and Fertilizer Technology Centre Taiwan 1-23.

Kell, D.B., Kaprelyants, AS, Weichart, DH et al. (1998). Viability and activity in readily culturable bacteria: A review and discussion of the practical issues. Antonie van Leeuwenhoek 73:169-187.

Kim, M., Oh, H., Park, S., Chun, J. (2014). Towards a taxonomic coherence between average nucleotide identity and 16S rRNA gene sequence similarity for species demarcation of prokaryotes. IJSEM 64:346-351

https://dx.doi.org/10.1099/ijs.0.059774-0

Kimura, M, Wada, H and Takai, Y. (1977). Studies of the rhizosphere of paddy rice (Part 4). Physical and chemical features of rhizosphere (II). J Sci. Soil Manure Jpn. 48:540-545.

Kimura, M., Wada, H., Takai, Y. (1983). Rice rhizosphere as environment of microbial growth. Soil and Microbiol. 25:45-55.

Labeda, D.P. (1990). Isolation of biotechnological organisms from nature. McGraw Publishing Company 1990, New York.

Lauber, C.L., Ramirez, K.S., Aanderud, Z. et al. (2013). Temporal variability in soil microbial communities across land-use types. The ISME Journal 2013,1-10.

Liesack, W., Schnell, S. and Revsbech, N.P. (2000). Microbiology of flooded rice paddies. FEMS Microbiol. Rev. 2000;24:625-645.

https://onlinelibrary.wiley.com/doi/full/10.1111/j.1574-

6976.2000.tb00563.x?sid=nlm\%3Apubmed

Lopes, A.R., Faria, C., Prieto-Fernández, A. et al. (2011). Comparative study of the microbial diversity of bulk paddy soil of two rice fields subjected to organic and conventional farming. Soil Biology and Biochemistry 43(1):115-125. http://dx.doi.org/10.1016/j.soilbio.2010.09.021

Luo, C., Walk, S.T., Gordon, D.M. et al. (2011). Genome sequencing of environmental Escherichia coli expands understanding of the ecology and speciation of the model bacterial species. Proc Natl Acad Sci USA 2011;108:7200-7205. https://doi.org/10.1073/pnas.1015622108

Malaysia Standard (1980). Recommended Methods for Soil Chemical Analysis: Part I-V. Standards and Industrial Research Institute of Malaysia, Selangor 1980(678).

MARDI (Malaysian Agricultural Research and Development Institute) (2011) New technology can increase hill paddy yield. Malaysian Reserve, 18 Mar 2011. MARDI (Malaysian Agriculture Research and Development Institute) (1992) Requirement of Rice after Two Decades Double Cropping in Malaysia. In Proceedings of International Symposium on Paddy Soils, Nanjing, China 2000; 283-289. 
Mizrahi-Man, O., Davenport, E.R., Gilad, Y. (2013). Taxonomic Classification of Bacterial 16S rRNA Genes Using Short Sequencing Reads: Evaluation of Effective Study Designs, PLoS One 2013;5:e53608.

Muramatsu, H., Shahab, N., Tsurumi, Y., and Hino, M.A. (2003). Comparative Study of Malaysian and Japanese Actinomycetes Using a Simple Identification Method Based on Partial 16S rDNA Sequence. Actinomycetol. 17:33-43.

Omura, S. (2011). Microbial Metabolites: 45 Years of Wandering, Wondering and Discovering. Tetrahedron 67:6420-6459.

Panthier, J.J., Dien, H.G., and Dommergues, Y. (1979). Rapid method to enumerate and isolate soil actinomycetes antagonistic towards rhizobia. Soil. Biol. Biochem. 11:443-445.

Plaster, E.J. (2002). Physical Properties of soil. Soil Science and Management. Delmar Learning.

Potts, M. (1994). Desiccation tolerance of prokaryotes. Microbiol. Rev. 58:755805

Rondon, M.R., August, P.R., Bettermann, A.D. et al. (2000). Cloning the soil metagenome: a strategy for accessing the genetic and functional diversity of uncultured microoragnisms. Appl. Environ. Microbiol. 66:2541-2547.

Roper, M.M., Ophel-Keller, K.M. (1997). Soil microflora as bioindicators of soil health. In: Pankhurst, C., Doube, B.M., Gupta, V.V.S.R. (eds). Biological indicators of soil health. CAB International, New York 7:157.

Rosselló-Mora, R., Amann, R. (2001). The species concept for prokaryotes FEMS Microbiol Rev. 25(1):39-67.

Rovira, A.D. (1969). Plant root exudates. Bot. Rev. 35:35-57.

Rule, P.L, Alexander, A.D. (1986). Gellan Gum as a substitute for agar in Leptospiral media. Journal of Clinical Microbiology 500-504. PMCID: PMC268682.

Saitou, N., Nei, M. (1987). The neighbour-joining method: A new method for reconstructing phylogenetic trees. Molecular Biology and Evolution 4:406-425.

Saranraj, P., Sivasakthivelan, P., Sakthi, S.S. (2013). Prevalence and Production of Plant growth Promoting Substances by Pseudomonas flourescens. Isolates from Paddy Rhizophere Soil of Cuddalore District, Tamil Nadu, India. African Journal of Basic \& Applied Sciences 5(2): 95-101. https://pdfs.semanticscholar.org/8583/4c64b7605677c9b2329d7b52faa2aa3a1c21 .pdf

Sarawak Energy. Paddy Residues Potential (2013)

Schwarzenbach, K., Enkerli, J., Widmer, F.(2007). Objective criteria to assess representativity of soil fungal community profiles, Journal of Microbiological Methods 68(2), 358-366. https://doi.org/10.1016/j.mimet.2006.09.015

Shirling, E.B., Gottlieb, D. (1966). Methods for characterization of Streptomyces species. International Journal of Systematic Bacteriology Vol. 16, No. 3 July

1966 pp. 313-340. In Bergey's Manual of Systematic Bacteriology Vol. 4 (eds)

Williams, S.T., Sharpe, M.E. and Holt, J.P. pp. 2340-2343. Baltimore: Williams $\&$ Wilkins.

Silva, M.S., Sales, A.N., Magalhães-Guedes, K.T. et al. (2013). Brazilian

Cerrado Soil Actinobacteria Ecology. BioMed Research International. https://dx.doi.org/10.1155/2013/503805

Solecka, J., Zajko, J., Postek, M., Rajnisz, A. (2012). Biologically active secondary metabolites from Actinomycetes. Central European Journal of Biology 3;373-390. https://doi.org/10.2478/s11535-012-0036-1

Stackebrandt, E., Ebers, J. (2006). Taxonomic parameters revisited: tarnished gold standards. Microbiol Today 33:152-155.

Suzuki, S., Okuda, T., Komatsubara, S. (1999). Selective Isolation and Distribution of Sporichthya Strains in Soil. Appl. Environ. Microbiol. 65(5):1930. Sylvia, D.M., Fuhrmann, J.J., Hartel, P.G., Zuberer, D.A. (2005). Principles and applications of soil microbiology Prentice Hall, Upper Saddle River, NJ.

Takahashi, Y., Iwai, Y., Omura, S. (1986). Clostomicins, new antibiotics produced by Micromonospora echinospora subsp. armeniaca subsp. nov. II. Taxonomic study of the producing microorganism. J Antibiot (Tokyo) 39(10):1413-8.

Tamura, K., Nei, M., Kumar, S. (2004). Prospects for inferring very large phylogenies by using the neighbor-joining method. Proceedings of the National Academy of Sciences (USA) 101:11030-11035.

Tamura, K., Peterson, D., Peterson, N. et al. (2011). MEGA 5: Molecular

Evolutionary Genetics Analysis using Maximum Likelihood, Evolutionary

Distance, and Maximum Parsimony Methods. Molecular Biology and Evolution

28:2731-2739. https://doi.org/10.1093/molbev/msr121

Tindall, B.J., Rosselló-Móra, R., Busse, H.J. et al. (2010). Notes on the characterization of prokaryote strains for taxonomic purposes. IJSEM 60:249266. https://dx.doi.org/10.1099/ijs.0.016949-0

Torsvik, V. and Ovreas, L. (2002). Microbial diversity and function in soil: From genes to ecosystems. Current Opinion in Microbiology 5:240-245 DOI: 10.1016/S1369-5274(02)00324-7.

Trabue, S.L., Palmquist, D.E., Lydick, T.M., Singles S.K. (2006). Effects of soil storage on the microbial community and degradation of mersulfuron- methyl. Journal of Agriculture \& Food Chemistry 54:142-151.

Trujillo, M.E., Bacigalupe, R., Pujic, P. et al. (2014). Genome features of the endophytic Actinobacterium Micromonospora lupine strain Lupac 08: on the process of adaptation to an endophytic life style? PLOS one 9(9):e108522. https://doi.org/10.1371/journal.pone.0108522
Uhlirova, E., Elhottova, D., Triska, J., Santruckova, H. (2005). Physiology and Microbial Community Structure in Soil at Extreme Water Content. Folia Microbiol. 50(2):161-166..

Waksman, S.A. (1959). The Actinomycetes. I. Nature, Occurrence, and Activities Baltimore: The Williams and Wilkins Co.

WeatherSpark. Average Weather for Kuching, Malaysia.

Wolfe, B.E., Mummey, D.L., Rillig, M.C., Klironomos, J. (2007). Small-scale spatial heterogeneity of arbuscular mycorrhizal fungal abundance and community composition in a wetland plant community, Mycorrhiza 17(3):175-183. DOI: 10.1007/s00572-006-0089-y.

Wu, T., Chellemi, D.O., Graham, J.H. et al. (2008).Comparison of soil bacteria communities under diverse agricultural land management and crop production practices. Microb Ecol. 2008;55:293-310.

Xu, L., Li, Q., Jiang, C. (1996). Diversity of soil actinomycetes in Yunnan,

China. Appl. Environ. Microbiol. 62(1):244. PMCID: PMC1388754.

Zornoza, R., Guerrero, O.C., Mataix SJ et al. (2006). Assessing air-drying and rewetting pre-treatment effect on some enzyme activities under Mediterranean conditions. Soil Biology \& Biochemistry 38:2125-2134. https://dx.doi.org/10.1016/j.soilbio.2006.01.010 